Article

\title{
Dry and Wet Climate Periods over Eastern South America: Identification and Characterization through the SPEI Index
}

\author{
Anita Drumond ${ }^{1, *(1)}$, Milica Stojanovic ${ }^{2}\left(\mathbb{D}\right.$, Raquel Nieto ${ }^{3}\left(\right.$, Luis Gimeno $^{3}$, Margarida L. R. Liberato ${ }^{2,4} \oplus^{(}$, \\ Theotonio Pauliquevis ${ }^{1}\left(\mathbb{D}\right.$, Marina Oliveira ${ }^{1}$ and Tercio Ambrizzi ${ }^{5}(\mathbb{D}$ \\ 1 Instituto de Ciências Ambientais, Químicas e Farmacêuticas, Universidade Federal de São Paulo, \\ Diadema 09913-030, Brazil; theotonio.pauliquevis@unifesp.br (T.P.); oliveira.marina@unifesp.br (M.O.) \\ 2 Instituto Dom Luiz, Faculdade de Ciências da Universidade de Lisboa, 1749-016 Campo Grande, Portugal; \\ mstojanovic@fc.ul.pt (M.S.); mlr@utad.pt (M.L.R.L.) \\ 3 Environmental Physics Laboratory (EPhysLab), CIM-Uvigo, Universidade de Vigo, 32004 Ourense, Spain; \\ rnieto@uvigo.es (R.N.); 1.gimeno@uvigo.es (L.G.) \\ 4 Escola de Ciências e Tecnologia, Universidade de Trás-os-Montes e Alto Douro, 5001-801 Vila Real, Portugal \\ 5 Departamento de Ciências Atmosféricas, IAG, Universidade de São Paulo, São Paulo 05508-090, Brazil; \\ tercio.ambrizzi@iag.usp.br \\ * Correspondence: anita.drumond@unifesp.br
}

Citation: Drumond, A.; Stojanovic, M.; Nieto, R.; Gimeno, L.; Liberato, M.L.R.; Pauliquevis, T.; Oliveira, M.; Ambrizzi, T. Dry and Wet Climate Periods over Eastern South America: Identification and Characterization through the SPEI Index. Atmosphere 2021, 12, 155. https://doi.org/ 10.3390/atmos12020155

Academic Editor: Anthony R. Lupo Received: 22 December 2020

Accepted: 21 January 2021

Published: 26 January 2021

Publisher's Note: MDPI stays neutral with regard to jurisdictional claims in published maps and institutional affiliations.

Copyright: (c) 2021 by the authors. Licensee MDPI, Basel, Switzerland. This article is an open access article distributed under the terms and conditions of the Creative Commons Attribution (CC BY) license (https:// creativecommons.org/licenses/by/ $4.0 /)$.

\begin{abstract}
A large part of the population and the economic activities of South America are located in eastern regions of the continent, where extreme climate events are a recurrent phenomenon. This study identifies and characterizes the dry and wet climate periods at domain-scale occurring over the eastern South America (ESA) during 1980-2018 through the multi-scalar Standardized PrecipitationEvapotranspiration Index (SPEI). For this study, the spatial extent of ESA was defined according to a Lagrangian approach for moisture analysis. It consists of the major continental sink of the moisture transported from the South Atlantic Ocean throughout the year, comprising the Amazonia, central Brazil, and the southeastern continental areas. The SPEI for 1, 3, 6, and 12 months of accumulation was calculated using monthly precipitation and potential evapotranspiration time series averaged on ESA. The analysis of the climate periods followed two different approaches: classification of the monthly SPEI values as mild, moderate, severe, and extreme; the computation of the events and their respective parameters (duration, severity, intensity, and peak). The results indicate that wet periods prevailed in the 1990s and 2000s, while dry conditions predominated in the 2010s, when the longest and more severe dry events have been identified at the four scales.
\end{abstract}

Keywords: SPEI; eastern South America; extreme climate conditions; drought; wet episodes

\section{Introduction}

It is known that climate change may affect the frequency and intensity of extreme climate events [1]. In recent decades, South America has suffered from the alternation of extremely wet and dry climate conditions [2-5]. Droughts have affected different regions of Brazil such as Southeastern Brazil in 2014 [6-8] and the Amazon in 2010 and 2016 [9,10]. The Amazon region is especially vulnerable to the effects of extreme weather events such as prolonged droughts, changes in the rainy and dry seasons, and the risk of fire due to its ecosystem sensitivity. Two droughts in 2010 and 2016 and intense floods in 2012 and 2014 and their impacts on population and biodiversity have been well described in the literature [9-11]. Another important extreme climatic event that occurred in the 21st century was the prolonged drought in northeast Brazil during 2010-2016, which strongly affected the local agriculture and water reservoirs and has impacted the economy in the region [12,13]. Currently, the dry conditions observed over the Amazon rainforest and the Pantanal wetlands during 2020 are examples of how dry periods can enhance the propagation of fires, with enormous socio-economic and environmental damages, e.g., [14]. 
Several indices have been developed to identify wet and dry climate periods and to assess their severity, such as the Palmer Drought Severity Index [15] and the Standardized Precipitation Index (SPI) [16]. The World Meteorological Organization (WMO) recommends the use of SPI for operative monitoring purposes [17]. The main advantage of this index is its multi-scalar computation, which allows for the identification of extreme conditions at different accumulation periods and may affect different components of the hydrological cycle. The main disadvantage with the SPI is that calculations are exclusively based on precipitation and do not consider the influence of other meteorological variables on drought occurrence, such as the role of temperature through evapotranspirative processes [18]. For this reason, the Standardized Precipitation-Evapotranspiration Index (SPEI) [19] was developed following the same conceptual approach as the SPI, but it is based on the standardized difference between the precipitation (PRE) and potential evapotranspiration (PET).

As examples of applications of indices in the identification of dry events in South America, Drumond et al. [5] made use of the SPEI for the development of an online catalog of drought episodes in the Intergovernmental Panel on Climate Change (IPCC) reference regions from 1980 to 2015. In order to assess the drought events from 2011 to 2019 over Brazil, Cunha et al. 2019 [20] used the Integrated Drought Index (IDI), which combines a meteorological-based drought index and remote-sensing-based index. With the IDI, the authors were able to detect drought events in all Brazilian territories, i.e., north, center west, northeast, southeast, and south; in particular, the most severe drought event occurred in the northeast region $[12,13]$ and the most intense in the southeast region [6].

This work aims to identify and to characterize the wet and dry periods at domain-scale over the eastern South America (ESA) during 1980-2018 through the SPEI calculated at 1-, 3-, 6-, and 12-month accumulation periods. The spatial domain of ESA was defined for this study according to a Lagrangian methodology developed for moisture transport analysis. This approach was an alternative proposed to define the areal limits of the region according to the moisture source-sink relationship. Therefore, ESA consists in the major continental sink of the moisture transported from the Subtropical South Atlantic Ocean towards South America during the year, covering an area extending from the Amazon, central Brazil, and the southeastern continental areas.

This article consists in an extended version of the conference paper published in ECAS2020 [21] in which the domain-scale climate periods have been analyzed through the classification of monthly SPEI values (as mild, moderate, severe, and extreme), according to the criteria proposed by McKee et al. [16] for SPI. Now, it incorporates a more detailed analysis following a methodology also proposed by McKee et al. [16], in which dry and wet events were identified and characterized through the computation of their respective indicators (duration, severity, intensity, and peak). Section 2 explains the data, the Lagrangian analysis applied for the definition of the spatial extent of ESA, and the approaches applied for the identification and characterization of the dry and wet climate periods. Section 3 presents results; Section 4 provides the main conclusions.

\section{Data and Methodology}

\subsection{Data}

ERA-Interim global reanalysis dataset from the European Centre for Medium-Range Weather Forecasts (ECMWF) [22], with a horizontal resolution of $1^{\circ}$ on 61 vertical levels from the surface to $0.1 \mathrm{~h} \mathrm{~Pa}$, was used both in the identification of the South Atlantic moisture source region and as an input for the FLEXPART model (FLEXiblePARTicle dispersion model [23]. ERA-Interim reanalysis data are appropriate to feed the model because of the high-quality data for wind and specific humidity required by FLEXPART, as well as the reproduction of the hydrological cycle in a satisfactory way [24]. The dataset is provided by European Centre for Medium-Range Weather Forecasts (ECMWF) and is available at https:/ / www.ecmwf.int/en/forecasts/datasets/archive-datasets/reanalysisdatasets/era-interim [25]. 
The SPEI was computed using a time series of monthly PRE and PET from the Climate Research Unit (CRU) Time-Series (TS) Version 4.03 [26] at a spatial resolution of $0.5^{\circ}$. CRU TS is derived by the interpolation of monthly climate anomalies from extensive networks of weather station observations. PET is computed via the Penman-Monteith formula, using the CRU TS gridded values of mean temperature, vapor pressure, cloud cover, and static (temporally invariant except for the annual cycle) 1961-1990 average wind field values. Data of CRU TS 4.03 are provided by the University of East Anglia (UEA) together with Centre for Environmental Data Analysis (CEDA) and are available at https:/ / catalogue.ceda.ac.uk/uuid/10d3e3640f004c578403419aac167d82 [27].

The analysis covers the period from 1980 to 2018.

\subsection{Definition of the Lagrangian Approach for the Moisture Transport Analysis and the Study Area}

The South Atlantic moisture source region (SAT) was defined based on the maxima values of the annual climatological vertically integrated moisture flux (VIMF) divergence (values higher than $750 \mathrm{~mm}$ /year, which corresponds to approximately the 60th percentile of the positive values from the respective global climatology on the annual scale) following the same methodology by Gimeno et al. [28] (Figure 1a, grey area). SAT is placed over the South Atlantic Subtropical Anticyclone (SASA) region, the main feature of the atmospheric circulation over the South Atlantic Ocean, which affects the South American and African weather and climate [29].

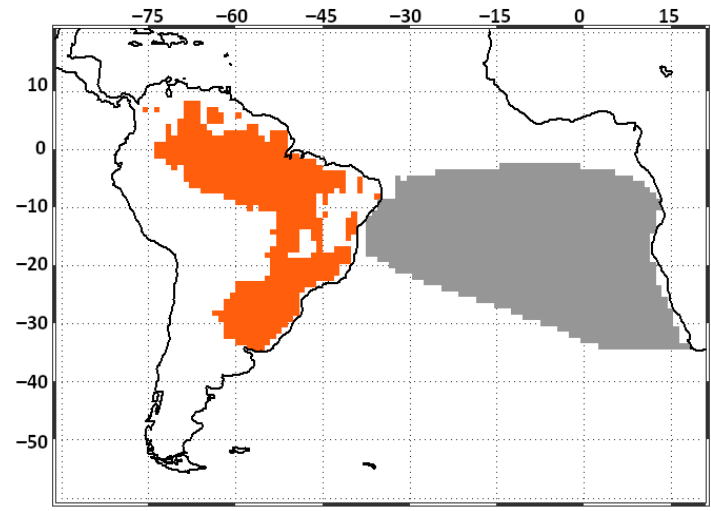

(a)

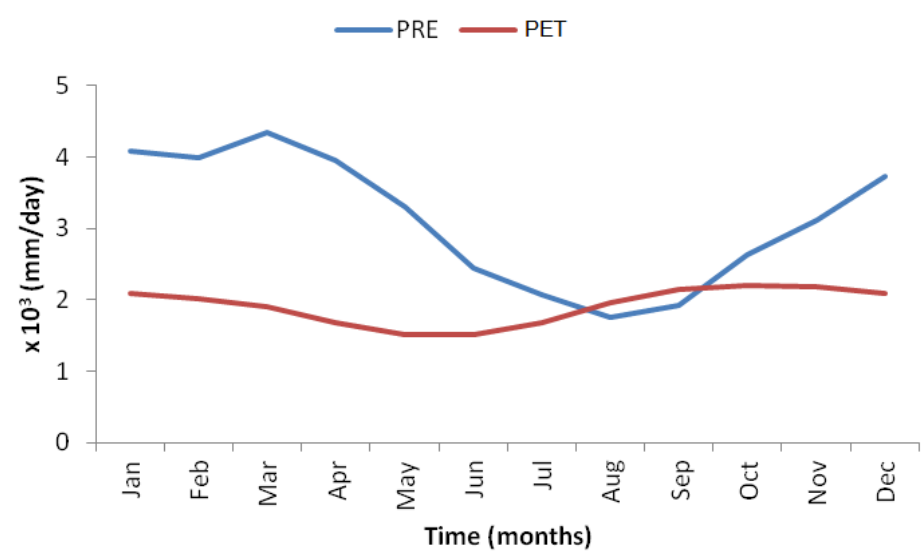

(b)

Figure 1. (a) In orange, the eastern South America (ESA) study region. ESA is a schematic representation of the annual sinks of moisture for the atmospheric particles that flow forward in time from the South Atlantic (SAT) source of moisture (in grey) for 10 days modeled by the FLEXPART model. The SAT is delimited based on the threshold of $750 \mathrm{~mm} /$ year for the annual climatological vertically integrated moisture flux (VIMF) divergence; (b) annual climatological precipitation cycle (PRE, blue line) and potential evapotranspiration (PET, red line) integrated over the ESA using data from the Climate Research Unit (CRU) Time-Series (TS) 4.03 database (scale in mm/day). Period of study: 1980-2018.

To identify the main SAT moisture sinks, the Lagrangian approach developed by Stohl and James $[30,31]$ using the FLEXPART model was applied. This methodology has been widely used with this purpose during recent decades [32-36]. In comparison with the Eulerian approaches, the Lagrangian methodology enables the tracking of air parcels, allowing the establishment of moisture source-receptor relationships in a more realistic way [36]. In the FLEXPART simulation, the global atmosphere was divided homogeneously into nearly 2.0 million particles with constant mass transported using 3D wind fields from the global reanalysis data ERA-Interim. The changes in specific humidity $(q)$ of each particle along its path were computed every $6 \mathrm{~h}$, and they can be expressed as $e-p=m(d q / d t)$, where $m$ is the mass of the particle, and $e-p$ represents the freshwater flux associated with each particle (evaporation $e$ minus precipitation $p$ ). The total $(E-P)$ represents the surface freshwater flux or the moisture budget associated with the tracked particles per unit area 
and was obtained by adding $(e-p)$ for all the particles residing in the atmospheric column over a given area.

In this study, the trajectories of the particles were tracked forward in time from the SAT moisture source to identify its sinks of the moisture (areas where the moisture budget of the air particles shows a supply of moisture to the atmosphere, i.e., precipitation exceeding evaporation, $E-P<0$ ). The track of the particles was followed for a period of 10 days (the average residence time of water vapor in the atmosphere [37]). The orange area in Figure 1a delimits schematically the major moisture sink area in South America selected using the 90th percentile of the negative values of the $(E-P)$ field, which corresponds with $-0.1 \mathrm{~mm}$ day-1, obtained from the annual global climatology (from 1980 to 2018). Those areas with $E-P<0$ over this threshold are in white, as same for those where $E$ exceeds $P$. This is the case for the "Polígono das Secas" region in northeastern Brazil, just westward of the SAT moisture source. Over this region, it is known that the air masses travelling from the southern Atlantic Ocean lose moisture only during its pre-rainy and rainy seasons (JanuaryMay), and during the remaining months, the evaporation dominates over precipitation [38]. Something similar occurs with the area in central Brazil where the evaporative processes dominate throughout the year $[5,39]$, thus providing moisture for precipitation for the South American subtropical latitudes.

Therefore, according to the results, the moisture contribution for the air masses travelling from the SAT occurs over the northeastern Amazon, central Brazil, and southeastern continental regions, areas which are affected by the wind flow associated with the western flank of the SASA and by the South American monsoon system [40]. This orange area, covering the lowers and subtropical latitudes in eastern South America, defines the spatial domain of our study area, herein namely as ESA.

\subsection{Identification and Characterization of Wet and Dry Climate Periods through SPEI}

Following the method applied by Drumond et al. [5] and Stojanovic et al. [41], time series of SPEI for 1980-2018 were calculated through time series of monthly PRE and PET averaged over the ESA, with the purpose of identifying the domain-scale wet and dry climate periods occurred over the region.

SPEI, based on the standardized difference between PRE and PET, was first proposed by Vicente-Serrano et al. as an improved drought index that is particularly suitable for studying the effect of global warming on drought severity [19]. This difference is calculated at various time scales (i.e., accumulation periods), and the resulting values are fit to a log-logistic probability distribution to transform the original values to standardized units that are comparable in space and time and at different SPEI time scales. Therefore, SPEI $-i$ is based on the difference between the values of PRE and PET over an $i$-month period. The time series is moving in the sense that the SPEI- $i$ value for each month is determined from the previous $i$ months. In other words, a SPEI-3 for December of a given year compares the October-November-December PRE-PET in that year with the OctoberDecember PRE-PET of all years available in the data. Details of the SPEI calculation can be found in $[19,42,43]$.

For this work, the 1-, 3-, 6-, and 12-month SPEI time scales were analyzed. Two approaches proposed by McKee et al. [16] are applied in the present work to identify and characterize the domain-scale ESA climate wet and dry periods based on the SPEI time series:

- The classification of monthly SPEI values according to their magnitude (Table 1);

- The identification of the domain-scale dry and wet events. A wet (dry) event starts when the SPEI value first falls above (below) zero (month included), followed by a value of 1 or higher ( -1 or less), and ends when the SPEI returns to a negative (positive) value (month not included). 
Table 1. Classification of Standardized Precipitation-Evapotranspiration Index (SPEI) values according to their magnitude. Adapted from [16].

\begin{tabular}{cc}
\hline SPEI & Category \\
\hline 2.0 and more & Extremely wet \\
1.5 to 1.99 & Severely wet \\
1.0 to 1.49 & Moderately wet \\
0.0 to 0.99 & Mild wet \\
-0.99 to 0.0 & Mild dry \\
-1.0 to -1.49 & Moderately dry \\
-1.5 to -1.99 & Severely dry \\
-2.0 and less & Extremely dry \\
\hline
\end{tabular}

Only events with onset after January 1980 and demise before December 2018 have been considered in the analysis. Four parameters characterizing the different events are then computed:

- Severity represents the absolute sum of all SPEI values during the event;

- Duration signifies the number of months between the first and last month of the event;

- Intensity is calculated as the ratio between the severity and duration;

- Peak value is the highest absolute SPEI value registered during the event.

\section{Results}

Figure $1 \mathrm{~b}$ shows the climatological annual cycle of the freshwater flux (PRE-PET) over our study region, the ESA (orange areas in Figure 1a) that covers the lowers and subtropical latitudes in the eastern continental region. PRE prevailed over PET throughout the year, except from August to September. Climatological PRE values present a well-defined annual cycle over the ESA, characterized by rainier Summer months (January-March) and a drier late Winter season (July-September); while climatological PET values over the ESA presents a minimum in the late Autumn season (May-June).

Figure 2 shows the time series of the SPEI on the scale of 1,3, 6, and 12 months over ESA to illustrate the evolution of the index on different time scales (conditions accumulated over monthly, seasonal, semiannual, and annual periods, respectively). Positive values in blue indicate wet periods, and negative values in red show dry conditions. Looking at Figure 2, one can see the predominance of wet periods during the mid-1990s and the decade of 2000 and of dry conditions during the decade of 2010. The dryness in the 2010s is evidenced by the high magnitude of the negative values evidenced mainly in the seasonal, semiannual, and annual accumulation periods (SPEI-3, -6 , and -12, respectively).

Looking at how wet and dry conditions (and its associated magnitude) over ESA varied during the decades, Figure 3 shows the number of occurrences of monthly SPEI-1, $-3,-6$, and -12 values at each one of the categories defined in Table 1 during the 1980s, 1990s, 2000s, and 2010s. This figure shows the predominance of wet conditions during the decade of 2000. On the other hand, Figure 3 shows that the 2010s concentrates the highest number of occurrences of dry SPEI values, particularly in the moderate and severe categories (at the scales -6 and -12). It deserves mention that the extremely dry conditions were reached in the four accumulation scales during the 2010s; moreover, the only extreme dry value at SPEI-12 was registered during this decade. 

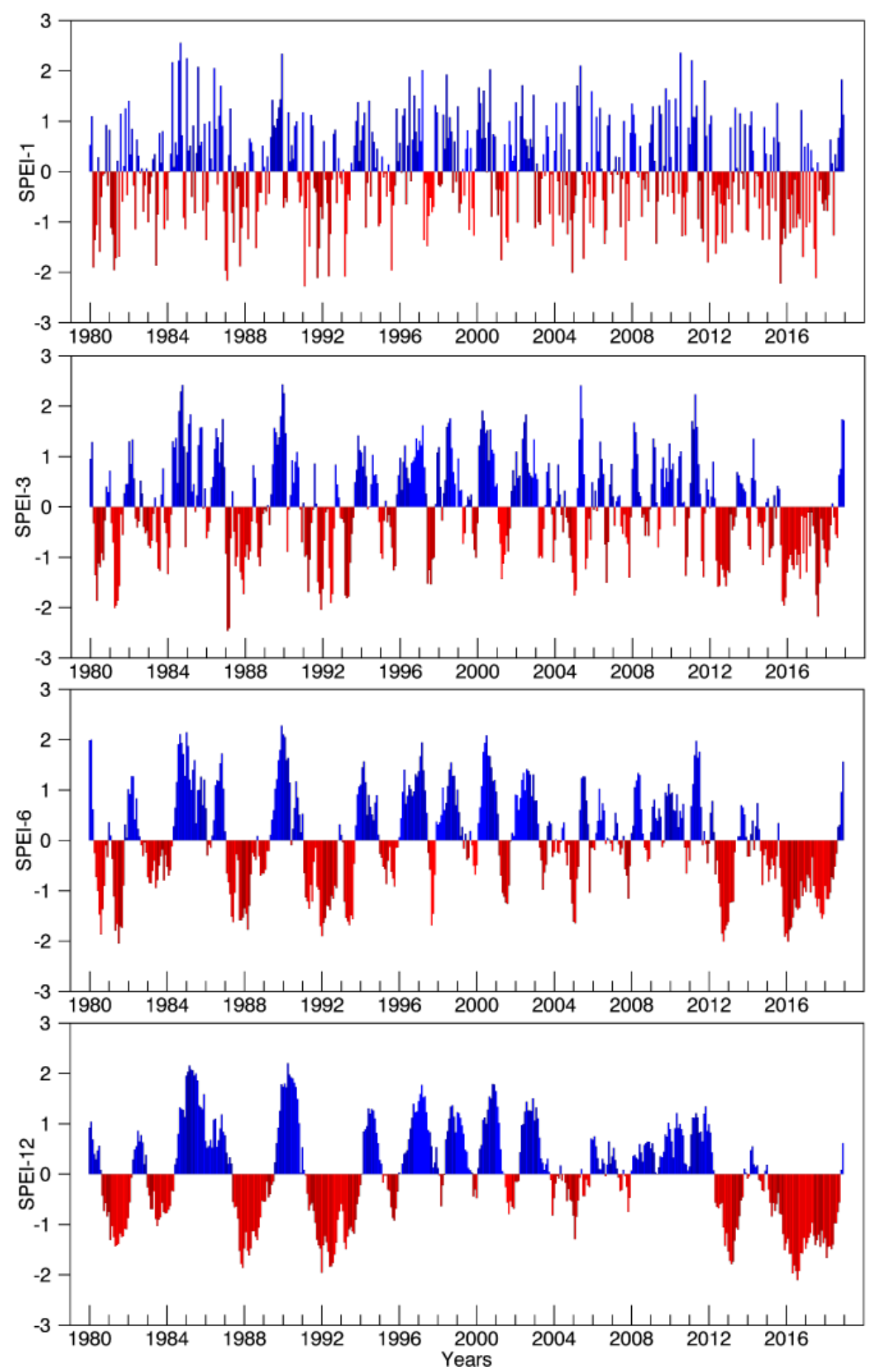

Figure 2. Time series of Standardized Precipitation-Evapotranspiration Index at the accumulation period of one month (SPEI-1), three months (SPEI-3), six months (SPEI-6), and twelve months (SPEI-12) for the ESA during 1980-2018. Data are computed from CRU TS 4.03. 

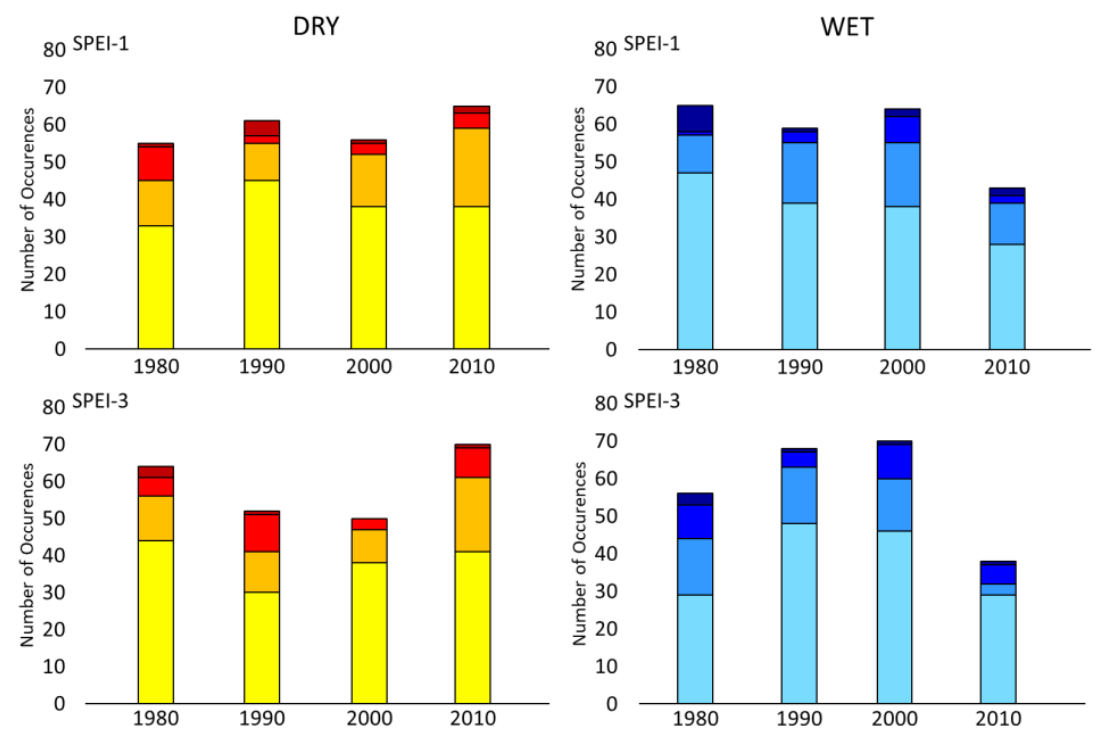

80 SPEI-3
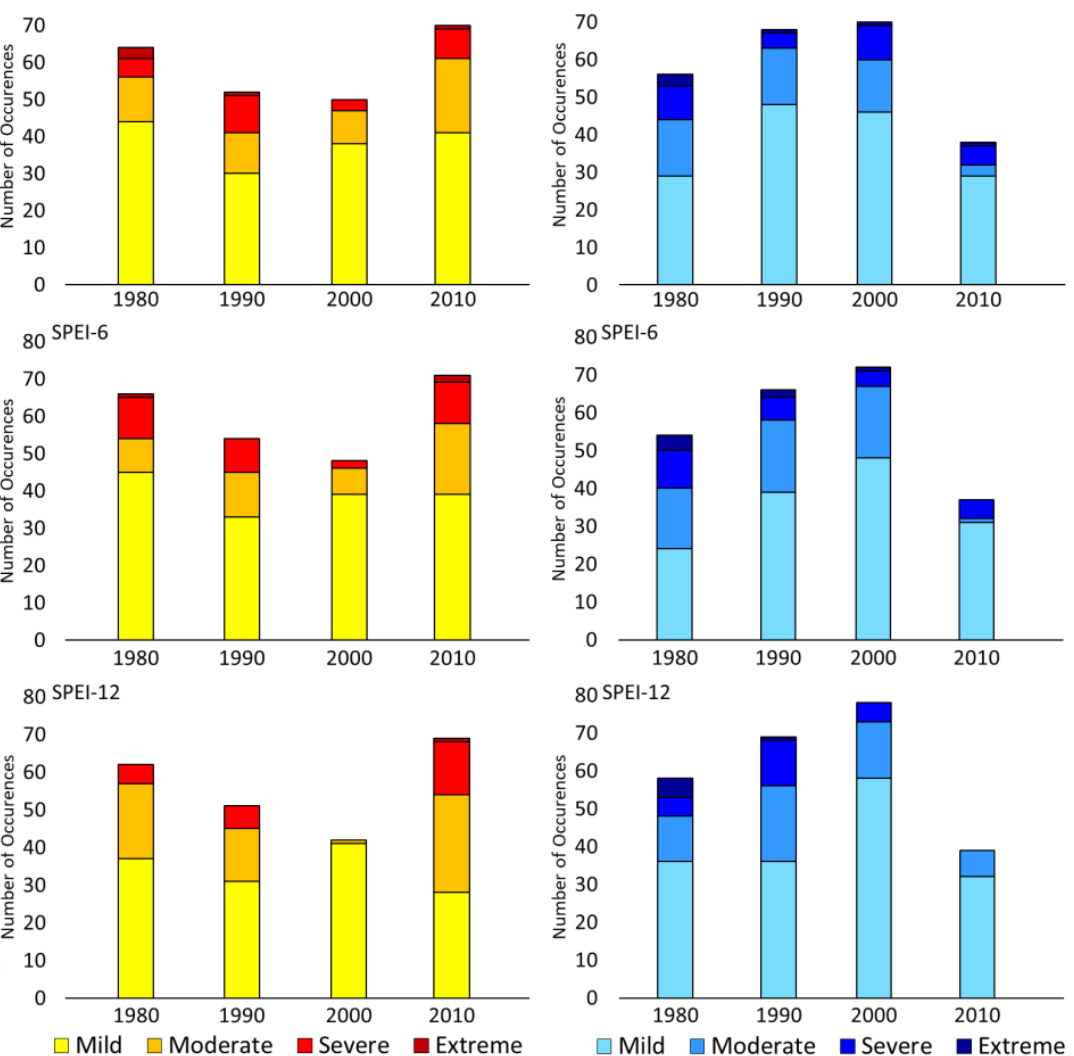

Figure 3. Number of occurrences of ESA SPEI-1, SPEI-3, SPEI-6, and SPEI-12 values at each one of the categories defined in Table 1 during the 1980s, 1990s, 2000s, and 2010s. Data are computed from CRU TS 4.03.

A joint analysis of dry and wet conditions at the different accumulation periods reveals that extreme wet conditions also occurred during the decade of 1980, although it was predominantly dry at seasonal, semiannual, and annual accumulation scales. A similar pattern was verified for the predominant dry conditions (reaching the category extreme) during the 1990s at the SPEI-1 scale in contrast to the wet conditions prevailing at the remaining scales.

Tables 2 and 3 (and Figures S1-S4 in the Supplementary Materials) show the dry and wet events (and their respective parameters) at domain-scale in ESA identified according to the criteria proposed by McKee et al. [16] at SPEI-1, SPEI-3, SPEI-6, and SPEI-12 accumulation periods. The number of dry events identified was higher than the wet ones at SPEI-1 (56 and 48, respectively) and SPEI-3 scales (27 and 22, respectively). The number of dry and wet events was quite similar for the SPEI-6 (12 and 15, respectively) and SPEI-12 (7 and 8 , respectively) scales. 
Table 2. Dry events at SPEI-1, -3, -6, and -12 over ESA for 1980-2018. For each scale, the events with a maximum in duration, severity, intensity, and peak are in gray and bold, italic, underline, and with asterisk.

\begin{tabular}{|c|c|c|c|c|c|c|c|c|c|c|c|}
\hline $\begin{array}{l}\infty \\
\underset{D}{D} \\
\underset{D}{0} \\
\frac{0}{0}\end{array}$ & 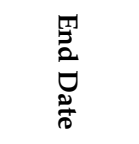 & 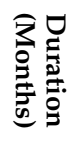 & $\begin{array}{l}\infty \\
\stackrel{\infty}{\&} \\
\stackrel{0}{\rightleftarrows} \\
\stackrel{\rightleftarrows}{4}\end{array}$ & 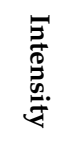 & D্ & 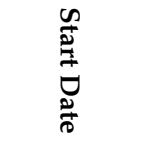 & $\begin{array}{l}\text { T్N } \\
\stackrel{0}{0} \\
\underset{0}{0}\end{array}$ & 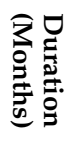 & 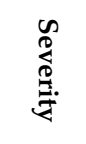 & 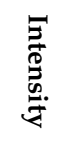 & $\begin{array}{l}0 \\
\stackrel{8}{2} \\
\stackrel{2}{2}\end{array}$ \\
\hline \multicolumn{6}{|c|}{ SPEI-1 } & \multicolumn{6}{|c|}{ SPEI-3 } \\
\hline 03/1980 & 05/1980 & 3 & 4.33 & 1.44 & 1.91 & 03/1980 & $10 / 1980$ & 8 & 8.11 & 1.01 & 1.87 \\
\hline $07 / 1980$ & $10 / 1980$ & 4 & 2.22 & 0.56 & 1.60 & 02/1981 & 09/1981 & 8 & 9.13 & 1.14 & 2.01 \\
\hline 02/1981 & 05/1981 & 4 & 6.04 & 1.51 & 1.96 & $06 / 1983$ & $08 / 1983$ & 3 & 3.19 & 1.06 & 1.27 \\
\hline 07/1981 & $07 / 1981$ & 1 & 1.69 & 1.69 & 1.69 & $11 / 1983$ & $03 / 1984$ & 5 & 3.13 & 0.63 & 1.33 \\
\hline $04 / 1982$ & 05/1982 & 2 & 1.42 & 0.71 & 1.15 & $01 / 1987^{*}$ & $\underline{04 / 1987^{*}}$ & 4 & 6.43 & $\underline{1.61}$ & $2.46^{*}$ \\
\hline $01 / 1983$ & $03 / 1983$ & 3 & 1.55 & 0.52 & 1.01 & $\overline{06 / 1987}$ & $\overline{05 / 1988}$ & 12 & 11.24 & $\overline{0.94}$ & 1.73 \\
\hline $06 / 1983$ & $07 / 1983$ & 2 & 2.72 & 1.36 & 1.87 & $08 / 1988$ & $02 / 1989$ & 7 & 3.59 & 0.51 & 1.18 \\
\hline $11 / 1983$ & $02 / 1984$ & 4 & 2.47 & 0.62 & 1.14 & 02/1991 & $07 / 1991$ & 6 & 5.05 & 0.84 & 1.69 \\
\hline $11 / 1984$ & $12 / 1984$ & 2 & 2.06 & 1.03 & 1.15 & $10 / 1991$ & 08/1992 & 11 & 12.99 & 1.18 & 2.04 \\
\hline $01 / 1986$ & 02/1986 & 2 & 1.97 & 0.98 & 1.36 & $12 / 1992$ & $08 / 1993$ & 9 & 7.99 & 0.89 & 1.81 \\
\hline $12 / 1986$ & $02 / 1987$ & 3 & 4.92 & 1.64 & 2.16 & $12 / 1994$ & 03/1995 & 4 & 2.53 & 0.63 & 1.03 \\
\hline $05 / 1987$ & 06/1987 & 2 & 2.23 & 1.11 & 1.41 & $05 / 1995$ & $10 / 1995$ & 6 & 4.10 & 0.68 & 1.26 \\
\hline $08 / 1987$ & $12 / 1987$ & 5 & 4.33 & 0.87 & 1.88 & 06/1997 & $10 / 1997$ & 5 & 6.36 & 1.27 & 1.54 \\
\hline $02 / 1988$ & $03 / 1988$ & 2 & 2.05 & 1.03 & 1.34 & $10 / 1999$ & $01 / 2000$ & 4 & 2.72 & 0.68 & 1.01 \\
\hline $08 / 1988$ & $11 / 1988$ & 4 & 3.16 & 0.79 & 1.52 & $02 / 2001$ & $09 / 2001$ & 8 & 6.45 & 0.81 & 1.43 \\
\hline $02 / 1991$ * & $05 / 1991$ * & 4 & 4.65 & 1.16 & $2.28 *$ & $03 / 2003$ & $06 / 2003$ & 4 & 3.43 & 0.86 & 1.02 \\
\hline $08 / 1991$ & $01 / 1992$ & 6 & 6.02 & 1.00 & 2.11 & $11 / 2003$ & $01 / 2004$ & 3 & 1.90 & 0.63 & 1.10 \\
\hline $03 / 1992$ & $07 / 1992$ & 5 & 4.27 & 0.85 & 2.08 & $08 / 2004$ & $02 / 2005$ & 7 & 6.82 & 0.97 & 1.76 \\
\hline $03 / 1993$ & $06 / 1993$ & 4 & 4.34 & 1.09 & 2.08 & $08 / 2005$ & $11 / 2005$ & 4 & 3.14 & 0.79 & 1.24 \\
\hline $04 / 1994$ & $05 / 1994$ & 2 & 1.33 & 0.67 & 1.11 & $08 / 2006$ & $10 / 2006$ & 3 & 2.95 & 0.98 & 1.51 \\
\hline $12 / 1994$ & $01 / 1995$ & 2 & 2.11 & 1.06 & 1.09 & $06 / 2007$ & $12 / 2007$ & 7 & 4.01 & 0.57 & 1.40 \\
\hline $07 / 1995$ & $10 / 1995$ & 4 & 3.30 & 0.83 & 1.97 & $10 / 2010$ & $12 / 2010$ & 3 & 2.58 & 0.86 & 1.37 \\
\hline 04/1997 & $10 / 1997$ & 7 & 5.98 & 0.85 & 1.48 & $08 / 2011$ & $10 / 2011$ & 3 & 2.59 & 0.86 & 1.39 \\
\hline $08 / 1999$ & 08/1999 & 1 & 1.16 & 1.16 & 1.16 & $05 / 2012$ & $05 / 2013$ & 13 & 13.34 & 1.03 & 1.59 \\
\hline $10 / 1999$ & $11 / 1999$ & 2 & 2.01 & 1.00 & 1.27 & $06 / 2014$ & $11 / 2014$ & 6 & 2.58 & 0.43 & 1.15 \\
\hline $01 / 2001$ & $05 / 2001$ & 5 & 3.72 & 0.74 & 1.76 & $02 / 2015$ & $04 / 2015$ & 3 & 2.60 & 0.87 & 1.00 \\
\hline $07 / 2001$ & $08 / 2001$ & 2 & 2.70 & 1.35 & 1.40 & 09/2015 & $04 / 2018$ & 32 & 31.64 & 0.99 & 2.18 \\
\hline $02 / 2002$ & $02 / 2002$ & 1 & 1.01 & 1.01 & 1.01 & \multicolumn{6}{|c|}{ SPEI-6 } \\
\hline $01 / 2003$ & $01 / 2003$ & 1 & 1.12 & 1.12 & 1.12 & $04 / 1980$ & $12 / 1980$ & 9 & 8.02 & 0.89 & 1.87 \\
\hline $03 / 2003$ & $05 / 2003$ & 3 & 2.19 & 0.73 & 1.06 & 03/1981* & $10 / 1981 *$ & 8 & 11.32 & $\underline{1.41}$ & 2.05 * \\
\hline $10 / 2003$ & $12 / 2003$ & 3 & 2.37 & 0.79 & 1.48 & $\overline{02 / 1987}$ & $\overline{08 / 1988}$ & 19 & 19.59 & $\overline{1.03}$ & 1.77 \\
\hline $06 / 2004$ & $06 / 2004$ & 1 & 1.01 & 1.01 & 1.01 & 02/1991 & 11/1992 & 22 & 23.77 & 1.08 & 1.90 \\
\hline $08 / 2004$ & $09 / 2004$ & 2 & 1.51 & 0.76 & 1.24 & $02 / 1993$ & $09 / 1993$ & 8 & 9.60 & 1.20 & 1.68 \\
\hline $11 / 2004$ & $02 / 2005$ & 4 & 4.27 & 1.07 & 2.01 & $07 / 1997$ & $11 / 1997$ & 5 & 4.66 & 0.93 & 1.69 \\
\hline $06 / 2005$ & $08 / 2005$ & 3 & 2.32 & 0.77 & 1.73 & $03 / 2001$ & $10 / 2001$ & 8 & 6.57 & 0.82 & 1.26 \\
\hline $10 / 2005$ & $11 / 2005$ & 2 & 1.27 & 0.63 & 1.02 & $08 / 2004$ & $04 / 2005$ & 9 & 7.39 & 0.82 & 1.65 \\
\hline $01 / 2006$ & $02 / 2006$ & 2 & 1.61 & 0.80 & 1.11 & $11 / 2005$ & $02 / 2006$ & 4 & 1.52 & 0.38 & 1.04 \\
\hline $07 / 2006$ & $09 / 2006$ & 3 & 3.16 & 1.05 & 1.43 & $09 / 2007$ & $12 / 2007$ & 4 & 2.93 & 0.73 & 1.15 \\
\hline $06 / 2007$ & $07 / 2007$ & 2 & 1.25 & 0.63 & 1.10 & $05 / 2012$ & $05 / 2013$ & 13 & 16.10 & 1.24 & 2.01 \\
\hline $09 / 2007$ & $11 / 2007$ & 3 & 2.99 & 1.00 & 1.76 & $09 / 2015$ & $08 / 2018$ & 36 & 41.19 & 1.14 & 2.01 \\
\hline $04 / 2009$ & $05 / 2009$ & 2 & 2.02 & 1.01 & 1.43 & \multicolumn{6}{|c|}{ SPEI-12 } \\
\hline $08 / 2010$ & $11 / 2010$ & 4 & 3.47 & 0.87 & 1.28 & $09 / 1980$ & 03/1982 & 19 & 18.51 & 0.97 & 1.44 \\
\hline $06 / 2011$ & $09 / 2011$ & 4 & 3.65 & 0.91 & 1.40 & $01 / 1983$ & $05 / 1984$ & 17 & 10.99 & 0.65 & 1.03 \\
\hline $12 / 2011$ & $12 / 2011$ & 1 & 1.80 & 1.80 & 1.80 & 06/1987 & $07 / 1989$ & 26 & 24.88 & 0.96 & 1.86 \\
\hline $03 / 2012$ & $01 / 2013$ & 11 & 9.04 & 0.82 & 1.63 & 03/1991 & $01 / 1994$ & 35 & 37.76 & 1.08 & 1.96 \\
\hline $03 / 2013$ & $04 / 2013$ & 2 & 1.42 & 0.71 & 1.21 & $06 / 2004$ & $05 / 2005$ & 12 & 5.77 & 0.48 & 1.29 \\
\hline $12 / 2013$ & $01 / 2014$ & 2 & 2.36 & 1.18 & 1.20 & $05 / 2012$ & $10 / 2013$ & 18 & 18.81 & 1.04 & 1.79 \\
\hline $05 / 2014$ & $10 / 2014$ & 6 & 3.06 & 0.51 & 1.36 & $\underline{02 / 2015^{*}}$ & $10 / 2018$ * & 45 & 55.52 & $\underline{1.23}$ & 2.10 * \\
\hline $01 / 2015$ & $02 / 2015$ & 2 & 2.02 & 1.01 & 1.35 & & & & & & \\
\hline $09 / 2015$ & $12 / 2015$ & 4 & 6.12 & 1.53 & 2.22 & & & & & & \\
\hline $02 / 2016$ & $09 / 2016$ & 8 & 6.40 & 0.80 & 1.22 & & & & & & \\
\hline $11 / 2016$ & $11 / 2016$ & 1 & 1.70 & 1.70 & 1.70 & & & & & & \\
\hline $01 / 2017$ & $01 / 2017$ & 1 & 1.11 & 1.11 & 1.11 & & & & & & \\
\hline $03 / 2017$ & $03 / 2017$ & 1 & 1.01 & 1.01 & 1.01 & & & & & & \\
\hline $06 / 2017$ & $07 / 2017$ & 2 & 3.65 & $\underline{1.82}$ & 2.11 & & & & & & \\
\hline$\overline{06 / 2018}$ & $\overline{06 / 2018}$ & 1 & 1.27 & $\overline{1.27}$ & 1.27 & & & & & & \\
\hline
\end{tabular}


Table 3. The same as Table 2, but for wet events. For each scale, the events with a maximum in duration, severity, intensity, and peak are in gray and bold, italic, underline, and with asterisk.

\begin{tabular}{|c|c|c|c|c|c|c|c|c|c|c|c|}
\hline & 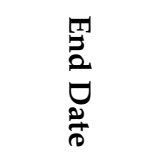 & 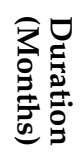 & 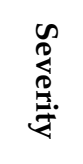 & 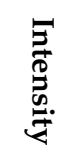 & D্2 & 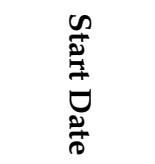 & 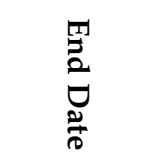 & 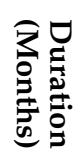 & 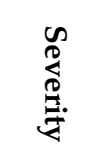 & $\begin{array}{l}\vec{E} \\
\overrightarrow{0} \\
\overrightarrow{0} \\
\overrightarrow{2} \\
\overrightarrow{2}\end{array}$ & $\begin{array}{l}\mathbb{2} \\
\stackrel{2}{2}\end{array}$ \\
\hline \multicolumn{6}{|c|}{ SPEI-1 } & \multicolumn{6}{|c|}{ SPEI-3 } \\
\hline 08/1981 & 08/1981 & 1 & 1.15 & 1.15 & 1.15 & $10 / 1981$ & 04/1982 & 7 & 5.24 & 0.75 & 1.34 \\
\hline $10 / 1981$ & $11 / 1981$ & 2 & 1.37 & 0.68 & 1.26 & $04 / 1984$ * & $11 / 1984^{*}$ & 8 & 12.14 & 1.52 & 2.42 * \\
\hline 01/1982 & 03/1982 & 3 & 2.59 & 0.86 & 1.40 & $\overline{01 / 1985}$ & $\overline{05 / 1985}$ & 5 & 5.33 & 1.07 & 1.84 \\
\hline $03 / 1984$ * & $10 / 1984$ * & 8 & 9.01 & 1.13 & 2.56 * & $07 / 1985$ & $10 / 1985$ & 4 & 4.61 & 1.15 & 1.58 \\
\hline 01/1985 & 03/1985 & 3 & 3.18 & 1.06 & 2.25 & $04 / 1986$ & $12 / 1986$ & 9 & 9.78 & 1.09 & 1.74 \\
\hline $07 / 1985$ & $10 / 1985$ & 4 & 3.56 & 0.89 & 2.08 & 05/1989 & 02/1990 & 10 & 14.72 & 1.47 & 2.43 \\
\hline 03/1986 & $07 / 1986$ & 5 & 4.19 & 0.84 & 2.06 & $05 / 1990$ & $10 / 1990$ & 6 & 4.42 & 0.74 & 1.09 \\
\hline $09 / 1986$ & $11 / 1986$ & 3 & 3.73 & 1.24 & 1.71 & $09 / 1993$ & 04/1994 & 8 & 7.48 & 0.93 & 1.42 \\
\hline $03 / 1987$ & 04/1987 & 2 & 1.58 & 0.79 & 1.25 & 06/1994 & $11 / 1994$ & 6 & 3.24 & 0.54 & 1.03 \\
\hline 05/1989 & 12/1989 & 8 & 9.98 & 1.25 & 2.34 & 11/1995 & 05/1997 & 19 & 16.59 & 0.87 & 1.62 \\
\hline 04/1990 & 09/1990 & 6 & 4.05 & 0.67 & 1.18 & 11/1997 & 02/1998 & 4 & 2.71 & 0.68 & 1.19 \\
\hline $01 / 1991$ & 01/1991 & 1 & 1.18 & 1.18 & 1.18 & $04 / 1998$ & 03/1999 & 12 & 9.75 & 0.81 & 1.76 \\
\hline 06/1991 & 07/1991 & 2 & 2.04 & 1.02 & 1.13 & $02 / 2000$ & $01 / 2001$ & 12 & 14.89 & 1.24 & 1.91 \\
\hline $07 / 1993$ & 03/1994 & 9 & 6.01 & 0.67 & 1.38 & $10 / 2001$ & $02 / 2003$ & 17 & 13.94 & 0.82 & 1.83 \\
\hline 06/1994 & 06/1994 & 1 & 1.41 & 1.41 & 1.41 & $03 / 2005$ & $07 / 2005$ & 5 & 6.53 & 1.31 & 2.41 \\
\hline 11/1995 & $01 / 1996$ & 3 & 2.03 & 0.68 & 1.25 & $04 / 2006$ & $07 / 2006$ & 4 & 3.46 & 0.87 & 1.30 \\
\hline $03 / 1996$ & 04/1996 & 2 & 2.37 & 1.18 & 1.26 & $01 / 2008$ & $06 / 2008$ & 6 & 5.47 & 0.91 & 1.68 \\
\hline 06/1996 & 07/1996 & 2 & 2.40 & 1.20 & 1.88 & $01 / 2009$ & $04 / 2009$ & 4 & 3.08 & 0.77 & 1.36 \\
\hline $09 / 1996$ & 03/1997 & 7 & 7.21 & 1.03 & 2.01 & $07 / 2009$ & $02 / 2010$ & 8 & 6.25 & 0.78 & 1.26 \\
\hline $11 / 1997$ & $12 / 1997$ & 2 & 2.49 & 1.25 & 1.32 & $05 / 2010$ & $09 / 2010$ & 5 & 2.85 & 0.57 & 1.10 \\
\hline $04 / 1998$ & 09/1998 & 6 & 6.05 & 1.01 & 1.93 & $01 / 2011$ & $07 / 2011$ & 7 & 8.65 & 1.24 & 2.24 \\
\hline 01/1999 & $01 / 1999$ & 1 & 1.29 & 1.29 & 1.29 & $03 / 2014$ & $05 / 2014$ & 3 & 2.45 & 0.82 & 1.35 \\
\hline 12/1999 & $06 / 2000$ & 7 & 6.84 & 0.98 & 1.67 & \multicolumn{6}{|c|}{ SPEI-6 } \\
\hline $08 / 2000$ & $09 / 2000$ & 2 & 3.01 & 1.50 & 2.03 & $11 / 1981$ & 08/1982 & 10 & 6.41 & 0.64 & 1.28 \\
\hline $09 / 2001$ & $01 / 2002$ & 5 & 3.43 & 0.69 & 1.38 & $05 / 1984$ & $01 / 1986$ & 21 & 26.40 & 1.26 & 2.15 \\
\hline $03 / 2002$ & $12 / 2002$ & 10 & 7.56 & 0.76 & 1.71 & 05/1986 & 01/1987 & 9 & 8.43 & 0.94 & 1.73 \\
\hline $01 / 2004$ & $02 / 2004$ & 2 & 1.78 & 0.89 & 1.36 & $05 / 1989 *$ & $05 / 1990$ * & 13 & 17.57 & 1.35 & 2.28 * \\
\hline $07 / 2004$ & $07 / 2004$ & 1 & 1.38 & 1.38 & 1.38 & 07/1990 & 01/1991 & 7 & 4.09 & 0.58 & 1.17 \\
\hline $03 / 2005$ & $05 / 2005$ & 3 & 5.13 & 1.71 & 2.11 & $10 / 1993$ & $12 / 1994$ & 15 & 12.30 & 0.82 & 1.57 \\
\hline $12 / 2005$ & $12 / 2005$ & 1 & 1.60 & 1.60 & 1.60 & $01 / 1996$ & 06/1997 & 18 & 18.95 & 1.05 & 1.95 \\
\hline $03 / 2006$ & $06 / 2006$ & 4 & 2.81 & 0.70 & 1.26 & $12 / 1997$ & 04/1999 & 17 & 13.16 & 0.77 & 1.55 \\
\hline $10 / 2006$ & $11 / 2006$ & 2 & 2.05 & 1.02 & 1.13 & $02 / 2000$ & $02 / 2001$ & 13 & 16.53 & 1.27 & 2.09 \\
\hline $08 / 2007$ & $08 / 2007$ & 1 & 1.00 & 1.00 & 1.00 & $11 / 2001$ & $03 / 2003$ & 17 & 15.23 & 0.90 & 1.41 \\
\hline $12 / 2007$ & $03 / 2008$ & 4 & 4.01 & 1.00 & 1.35 & $05 / 2005$ & $10 / 2005$ & 6 & 5.51 & 0.92 & 1.27 \\
\hline $12 / 2008$ & $03 / 2009$ & 4 & 3.01 & 0.75 & 1.29 & $03 / 2006$ & $08 / 2006$ & 6 & 3.30 & 0.55 & 1.03 \\
\hline $06 / 2009$ & $07 / 2009$ & 2 & 2.45 & 1.23 & 1.31 & $01 / 2008$ & $08 / 2008$ & 8 & 6.06 & 0.76 & 1.34 \\
\hline $09 / 2009$ & $10 / 2009$ & 2 & 1.77 & 0.88 & 1.65 & $10 / 2009$ & 09/2010 & 12 & 8.95 & 0.75 & 1.12 \\
\hline $12 / 2009$ & $01 / 2010$ & 2 & 1.72 & 0.86 & 1.42 & $02 / 2011$ & $08 / 2011$ & 7 & 9.54 & $\underline{1.36}$ & 1.98 \\
\hline $04 / 2010$ & $05 / 2010$ & 2 & 2.35 & 1.17 & 1.45 & \multicolumn{6}{|c|}{ SPEI-12 } \\
\hline $07 / 2010$ & $\underline{07 / 2010}$ & 1 & 2.36 & $\underline{2.36}$ & 2.36 & 06/1984 & 05/1987 & 36 & 39.19 & 1.09 & 2.16 \\
\hline$\overline{12 / 2010}$ & $05 / 2011$ & 6 & 7.11 & 1.18 & 2.21 & 08/1989* & 02/1991* & 19 & 24.75 & $\underline{1.30}$ & 2.20 * \\
\hline $10 / 2011$ & $11 / 2011$ & 2 & 2.52 & 1.26 & 1.81 & $02 / 1994$ & $02 / 1995$ & 13 & 10.77 & 0.83 & 1.30 \\
\hline $01 / 2012$ & $02 / 2012$ & 2 & 2.05 & 1.02 & 1.11 & $01 / 1996$ & $01 / 1998$ & 25 & 20.49 & 0.82 & 1.77 \\
\hline $05 / 2013$ & $06 / 2013$ & 2 & 1.34 & 0.67 & 1.27 & 06/1998 & $10 / 1999$ & 17 & 13.79 & 0.81 & 1.37 \\
\hline $08 / 2013$ & $08 / 2013$ & 1 & 1.16 & 1.16 & 1.16 & $02 / 2000$ & 06/2001 & 17 & 16.86 & 0.99 & 1.79 \\
\hline $02 / 2014$ & $04 / 2014$ & 3 & 2.53 & 0.84 & 1.20 & $04 / 2002$ & $10 / 2003$ & 19 & 15.74 & 0.83 & 1.51 \\
\hline $07 / 2015$ & $08 / 2015$ & 2 & 1.95 & 0.98 & 1.37 & $06 / 2009$ & $04 / 2012$ & 35 & 25.40 & 0.73 & 1.35 \\
\hline $10 / 2016$ & $10 / 2016$ & 1 & 1.22 & 1.22 & 1.22 & & & & & & \\
\hline
\end{tabular}


In order to illustrate the time evolution of the occurrence of the events listed in Tables 2 and 3, Figure 4 shows the dry and wet events at domain-scale in ESA over the four accumulation periods during the study period. It is worth noting that the climatological conditions in the late 2000s at annual accumulation scale (SPEI-12) probably associated with the alternation between the wet and dry events configured at shorter scales during that period. One can see the evolution of the wet events on different time scales during the 1990s and 2000s, as well as of the dry ones during the decade of 2010.

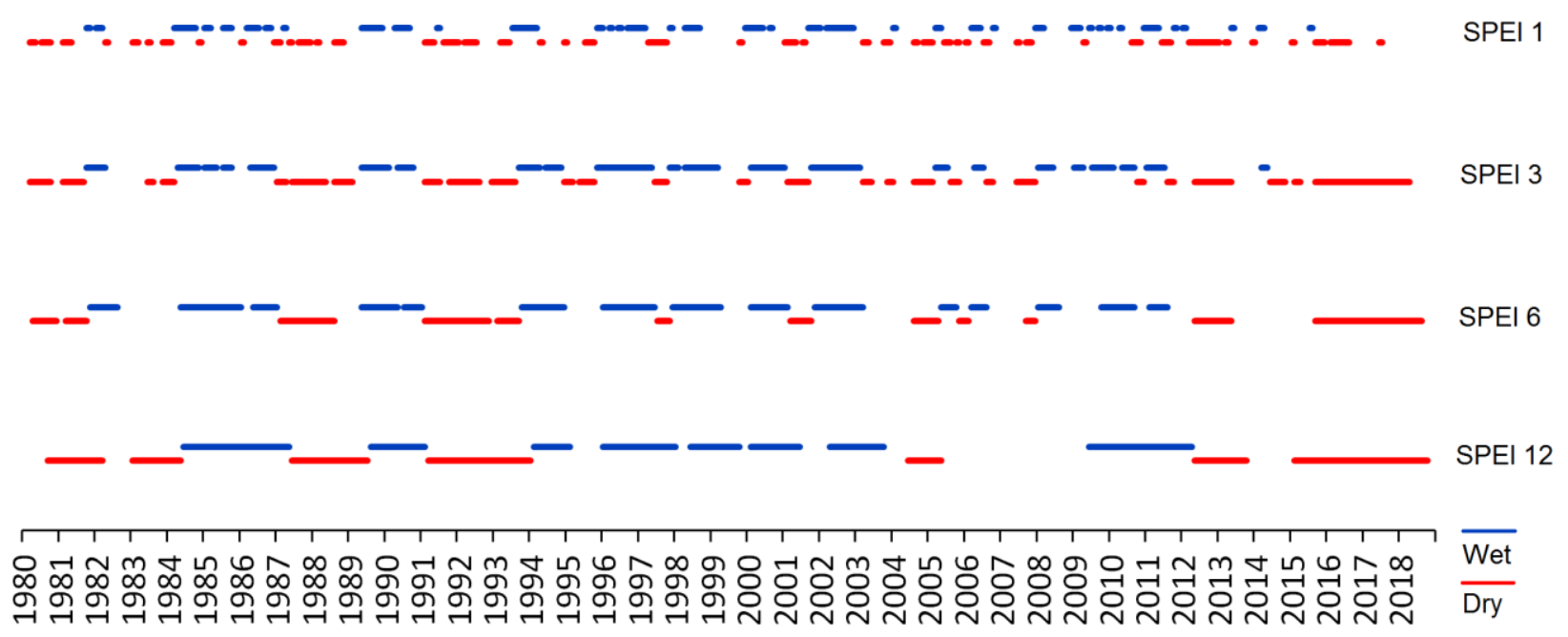

Figure 4. SPEI-1, SPEI-3, SPEI-6, and SPEI-12 dry (red) and wet (blue) events that occurred over the ESA during 1980-2018. The episodes were identified following the criteria of McKee et al. [16]. White parts of the plot mean neutral periods.

A closer look at Tables 2 and 3 and Figures S1-S4 reveals more details about the characteristics of the dry and wet events identified. For each parameter and scale, the highest value appears highlighted in the tables. Although most of the wet events presenting the highest values of the parameters investigated at the four scales have been registered during the decade of 1980 (Table 3), the most intense dry events (also presenting the highest peaks) at SPEI-3 and SPEI-6 were identified during the 1980s (January-April 1987 and March-October 1981, respectively). A similar pattern was verified during the 1990s. Although this decade has been characterized by wet conditions at SPEI-3, SPEI-6, and SPEI-12 scales, the dry event of February-May 1991 presented the highest peak at SPEI-1 (Table 2), even short in duration (4 months). It deserves attention that the longest and more severe dry events at the four scales have been identified during the decade of 2010 (Table 2), confirming the persistence of dry conditions over ESA in that period. For instance, the most severe dry events (with onset in 2015) identified at SPEI-3, -6, and -12 lasted more than 30 months in these scales.

Boxplot diagrams summarizing the distribution of the parameters associated with the dry and wet events at the four accumulation periods are shown in the Figure 5. In general, dry and wet events at each scale present a quite similar distribution of duration. There is no statistical significance in the difference between the samples of wet and dry events, although there are longer dry events in comparison with the wet ones, such as the dry events with onset in 2015. The median varies from 2 months at SPEI-1 to 19 months at SPEI12. The median of intensity of the events at the four scales is around 0.9 , although there were more intense events at SPEI- 1 in comparison with the remaining scales. Concerning severity, the median varies from around 2 at SPEI-1 to 18 at SPEI-12. The median of the peak of events varies from around 1.4 at SPEI-1 to approximately 1.7 at SPEI-12. 

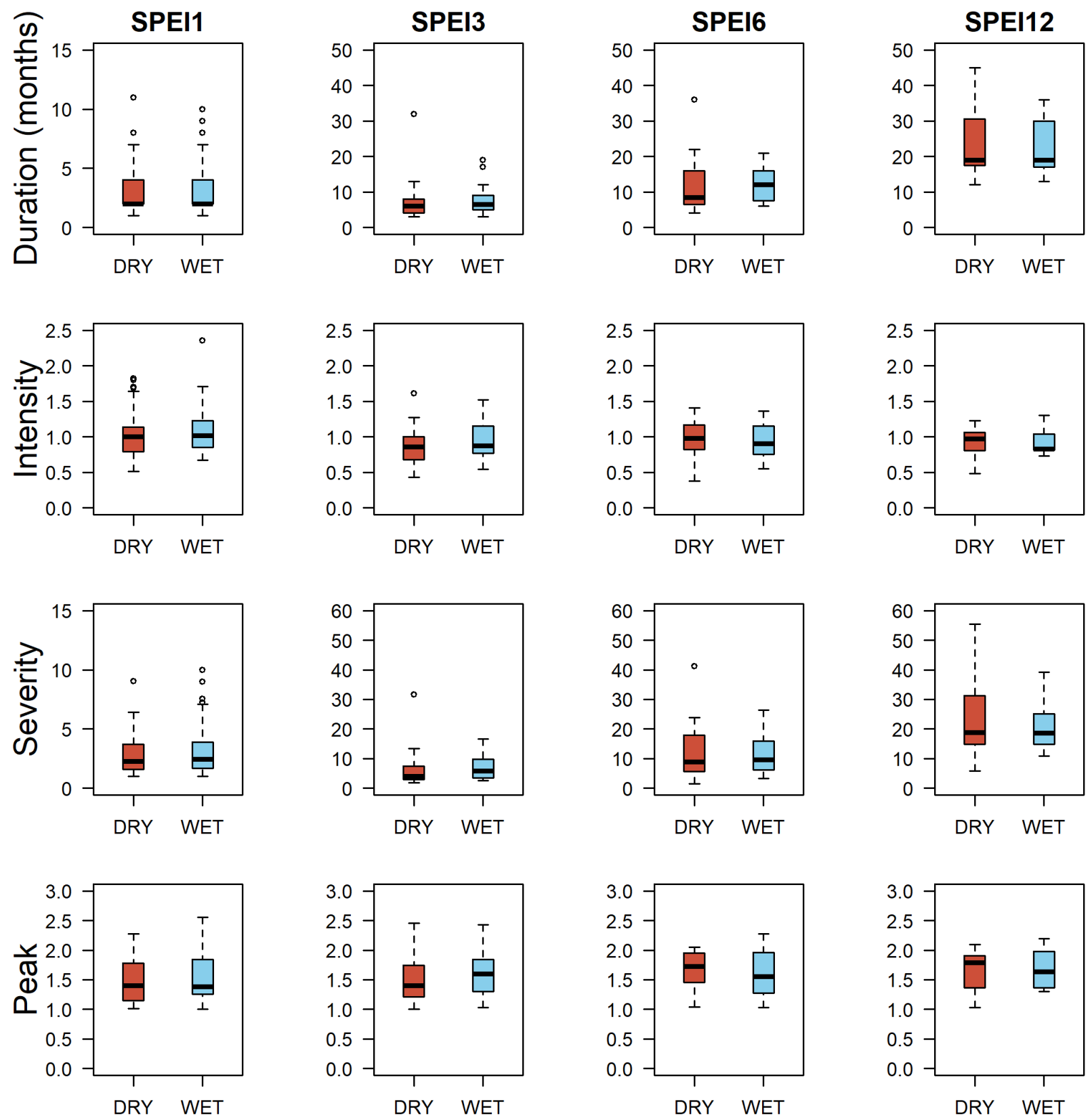

Figure 5. Boxplot diagrams for the four parameters (duration, intensity, severity, peak; lines) characterizing the climate dry (reddish boxes) and wet (bluish boxes) events identified at domain-scale over ESA during 1980-2018 at SPEI-1, SPEI-3, SPEI-6, and SPEI-12 (columns). Boxes delineate the median, upper, and lower quartiles, with the whiskers representing the lowest and highest value for the parameters associated with the events. Tables 2 and 3 list the dry and wet events, respectively. Data are from CRU TS 4.03.

\section{Summary and Conclusions}

In the present study, the dry and wet climate events at domain-scale occurring over the eastern South American (ESA) region during 1980-2018 were identified and characterized through the multi-scalar Standardized Precipitation-Evapotranspiration Index (SPEI) at the SPEI-1, SPEI-3, SPEI-6, and SPEI-12 accumulation periods. The spatial domain of ESA was defined for this study based on a Lagrangian approach developed for moisture transport analysis, and it consists in the major continental sink of the moisture transported from the Subtropical South Atlantic Ocean towards South America. ESA covers an area extending from the Amazon, central Brazil, and reaching the southeastern continental areas. The wet and dry climate periods were then identified and characterized over ESA through two 
different methodologies proposed by McKee et al. [16]: the SPEI values (classified as mild, moderate, severe, and extreme) and the events (and their respective parameters: duration, severity, intensity, and peak). The main conclusions are summarized:

- The climatological annual cycle of the freshwater flux over ESA shows that precipitation prevailed over potential evapotranspiration during the year, except from August to September. ESA is characterized by rainier Summer months and a drier Winter season.

- Although the decade of 1980 presented the highest number of extremely wet values in the SPEI-1, $-3,-6$, and -12 accumulation periods, it was also characterized by the predominance of dry values in the SPEI- $3,-6$, and -12 scales. The most intense dry events (also presenting the highest peaks) at SPEI-3 and SPEI-6 were identified during the 1980s. However, most of the wet events presenting the highest magnitude of the parameters investigated at the four scales have been registered during the decade of 1980. In other words, results indicate that wet and dry conditions occurred during this period.

- Both approaches confirm the predominance of wet conditions during the decade of 1990 and 2000, except for the SPEI-1. It is worth noting that the decade of 1990 presented the highest number of extremely dry values in the SPEI-1time series, registering the dry event with the highest peak at SPEI-1.

- The 2010s concentrates the highest number of occurrences of dry SPEI values, particularly the moderate ones. The longest and more severe dry events at the four scales have been identified during this period.

The predominance of climate dry conditions during the 2010s was also highlighted in [20]. According to their results, dry events were widespread over Brazil especially from 2011 to 2017. With exception of the south region, the other Brazilian regions have been exposed to the most severe and intense dry events in decades, such as the 2014/2015 event in the southeast region, the 2015/2016 event in the Amazon, and the 2011-2017 event in northeast Brazil.

Attribution studies to identify whether the increase in the frequency of the wet and dry events registered during the 1980-2018 period over the ESA are due to natural or anthropogenic causes are still being developed. However, some possible physical explanation was given by Marengo et al. 2020 [44]. They found that changes in the position and intensity of the SASA are responsible for changes in the atmospheric circulation in the ESA. For instance, they showed that the SASA has slightly moved to the west and southward during the period of 1960 to 2019. They also analyzed the relationship between the phases of the Southern Annular Mode (SAM) and the position of the SASA. Although the focus of the Marengo et al. 2020 [44] was the climate variability impact in a metropolitan city in the ESA, their large-scale analysis clearly shows the humidity flux variability coming from the South Atlantic Ocean toward the region. Changes in the circulation can be important for the increase in the extreme wet and dry events observed in the period. Rodwell and Hoskins 2001 [45] showed that the spatial pattern of warming over the tropics in recent years has modified land-ocean temperature contrasts and sea level pressure gradients, the main drivers of the monsoonal circulation, then modulating the rainfall over the central and north part of the South American continent.

There is no doubt that further studies are needed to better understand the causes of the increase in the extreme events, which are probably related to the atmospheric warming that we are observing in our planet. Warmer temperatures increase evapotranspirative processes, which in turn may favor the establishment and intensification of dry conditions.

Supplementary Materials: The following are available online at https://www.mdpi.com/2073-4 433/12/2/155/s1, Figure S1: Duration (months) of the dry and wet events listed in Tables 2 and 3, respectively. Figure S2: Same as Figure S1, but for severity. Figure S3: Same as Figure S1, but for intensity. Figure S4: Same as Figure S1, but for peak. 
Author Contributions: Conceptualization and design of the calculations, A.D., L.G., T.A.; calculations, A.D., M.S., M.O.; analysis, A.D., M.S., R.N., L.G., M.L.R.L., T.A., T.P., M.O.; writing-original draft preparation, A.D.; writing—review and editing, A.D., M.S., R.N., L.G., M.L.R.L., T.P., M.O, T.A. All authors have read and agreed to the published version of the manuscript.

Funding: A.D. and M.O. acknowledge the support received by Fundação de Amparo à Pesquisa do Estado de São Paulo FAPESP (2020/09548-2). M.S. and M.L. acknowledge the Fundação para a Ciência e a Tecnologia (UIDB/50019/2020-IDL) and from Fundação para a Ciência e a Tecnologia and Portugal Horizon2020 through the project "Weather Extremes in the Euro Atlantic Region: Assessment and Impacts-WEx-Atlantic" (PTDC/CTA-MET/29233/2017). R.N. and L.G. thank the partially support by Xunta de Galicia under Project ED431C 2017/64-GRC “Programa de Consolidación e Estructuración de Unidades de Investigación Competitivas (Grupos de Referencia Competitiva)", co-funded by the European Regional Development Fund, European Union (FEDER). T.A. was supported by the National Institute of Science and Technology for Climate Change Phase 2 under CNPq Grant 465501/2014-1, FAPESP Grants 2014/50848-9 and 2017/09659-6 and also partially funded by CNPq grants 304298/2014-0 and 420262/2018-0.

Acknowledgments: The authors would like to thank two anonymous reviewers for their constructive comments and suggestions.

Conflicts of Interest: The authors declare no conflict of interest. The funders had no role in the design of the study; in the collection, analyses, or interpretation of data; in the writing of the manuscript, or in the decision to publish the results.

\section{References}

1. Intergovernmental Panel on Climate Change (IPCC). Climate Change 2014: Synthesis Report; Contribution of Working Groups I, II and III to the Fifth Assessment Report of the Intergovernmental Panel on Climate Change; Pachauri, R.K., Meyer, L.A., Eds.; IPCC: Geneva, Switzerland, 2014; 151p. Available online: https://www.ipcc.ch/pdf/assessment-report/ar5/syr/SYR_AR5_FINAL_ full_wcover.pdf (accessed on 23 January 2021).

2. Marengo, J.A.; Nobre, C.A.; Tomasella, J.; Cardoso, M.F.; Oyama, M.D. Hydro-climatic and ecological behaviour of the drought of Amazonia in 2005. Philos. Trans. R. Soc. B 2008, 363, 1773-1778. [CrossRef] [PubMed]

3. Marengo, J.A.; Alves, L.M.; Soares, W.R.; Rodriguez, D.A.; Camargo, H.; Riveros, M.P.; Pabló, A.D. Two Contrasting Severe Seasonal Extremes in Tropical South America in 2012: Flood in Amazonia and Drought in Northeast Brazil. J. Clim. 2013, 26, 9137-9154. [CrossRef]

4. Garreaud, R.D.; Alvarez-Garreton, C.; Barichivich, J.; Boisier, J.P.; Christie, D.; Galleguillos, M.; LeQuesne, C.; McPhee, J.; Zambrano-Bigiarini, M. The 2010-2015 megadrought in Central Chile: Impacts on regional hydroclimate and vegetation. Hydrol. Earth Syst. Sci. 2017, 21, 6307-6327. [CrossRef]

5. Drumond, A.; Stojanovic, M.; Nieto, R.; Vicente-Serrano, S.M.; Gimeno, L. Linking anomalous moisture transport and drought episodes in the IPCC reference regions. Bull. Am. Meteorol. Soc. 2019, 100, 1481-1498. [CrossRef]

6. Coelho, C.A.S.; de Oliveira, C.P.; Ambrizzi, T.; Reboita, M.S.; Bertoletti Carpenedo, C.; Pereira Silveira Campos, J.L.; Nóbile Tomaziello, A.C.; Nóbile Tomaziello, L.; de Souza Custódio, M.; Mosso Dutra, L.M.; et al. The 2014 southeast Brazil austral summer drought: Regional scale mechanisms and teleconnections. Clim. Dyn. 2016, 46, 3737-3752. [CrossRef]

7. Otto, F.E.L.; Haustein, K.; Uhe, P.; Coelho, C.A.S.; Aravequia, J.K.; Almeida, W.; King, A.; Coughlan de Perez, E.; Wada, Y.; van Oldenborgh, G.J.; et al. Factors other than climate change, main drivers of 2014/15 water shortage in southeast Brazil. Bull. Am. Meteorol. Soc. 2015, 96, S1-S172. [CrossRef]

8. Nobre, C.A.; Marengo, J.A.; Seluchi, M.E.; Cuartas, A.; Alves, L.M. Some Characteristics and Impacts of the Drought and Water Crisis in Southeastern Brazil during 2014 and 2015. J. Water Resour. Prot. 2016, 8, 252-262. [CrossRef]

9. Marengo, J.A.; Espinoza, J.C. Extreme seasonal droughts and floods in Amazonia: Causes, trends and impacts. Int. J. Climatol. 2016, 36, 1033-1050. [CrossRef]

10. Marengo, J.A., Jr.; Souza, C.; Thonicke, K.; Burton, C.; Halladay, K.; Betts, R.A.; Alves, L.M.; Soares, W.R. Changes in Climate and Land Use Over the Amazon Region: Current and Future Variability and Trends. Front. Earth Sci. 2018, 6, 228. [CrossRef]

11. Espinoza, J.C.; Marengo, J.A.; Ronchai, J.; Molina Carpio, J.; Noriega Flores, L.; Loup Guyot, J. The extreme 2014 flood in south-western Amazon basin: The role of tropical-subtropical South Atlantic SST gradient. Environ. Res. Lett. 2014, 9, 124007. [CrossRef]

12. Marengo, J.A.; Torres, R.R.; Alves, L.M. Drought in Northeast Brazil-Past, present, and future. Theor. Appl. Climatol. 2017, 129, 1189-1200. [CrossRef]

13. Marengo, J.A.; Alves, L.M.; Alvalá, R.C.; Cunha, A.P.; Brito, S.; Moraes, O.L. Climatic characteristics of the 2010-2016 drought in the semiarid Northeast Brazil region. An. Acad. Bras. Cienc. 2017, 90, 1973-1985. [CrossRef]

14. Brazil Fires Burn World 's Largest Tropical Wetlands at 'Unprecedented' Scale. Available online: https://www.nytimes.com/20 20/09/04/world/americas/brazil-wetlands-fires-pantanal.html (accessed on 18 January 2021). 
15. Palmer, W.C. Meteorological Drought; White, R.M., Ed.; U.S. Weather Bureau: Washington, DC, USA, 1965. Available online: https://www.ncdc.noaa.gov/temp-and-precip/drought/docs/palmer.pdf (accessed on 17 December 2020).

16. McKee, T.B.; Doesken, N.J.; Kleist, J. The relationship of drought frequency and duration to time scales. In Proceedings of the Eighth Conference on Applied Climatology, Boston, MA, USA, 17-22 January 1993; pp. 179-184. Available online: https:/ /www. droughtmanagement.info/literature/AMS_Relationship_Drought_Frequency_Duration_Time_Scales_1993.pdf (accessed on 17 December 2020).

17. Hayes, M.; Svodoba, M.; Wall, N.; Widhalm, M. The Lincoln Declaration on Drought Indices: Universal meteorological drought index recommended. Bull. Am. Meteorol. Soc. 2011, 92, 485-488. [CrossRef]

18. Otkin, J.A.; Svoboda, M.; Hunt, E.D.; Ford, T.W.; Anderson, M.C.; Hain, C.; Basara, B. Flash droughts: A review and assessment of the challenges imposed by rapid-onset droughts in the United States. Bull. Am. Meteorol. Soc. 2017, 99, 911-919. [CrossRef]

19. Vicente-Serrano, S.M.; Begueria, S.; Lopez-Moreno, J.I. A multiscalar drought index sensitive to global warming: The Standardized Precipitation Evapotranspiration Index. J. Clim. 2010, 23, 1696-1718. [CrossRef]

20. Cunha, A.P.M.A.; Zeri, M.; Deusdará Leal, K.; Costa, L.; Cuartas, L.A.; Marengo, J.A.; Tomasella, J.; Vieira, R.M.; Barbosa, A.A.; Cunningham, C.; et al. Extreme Drought Events over Brazil from 2011 to 2019. Atmosphere 2019, 10, 642. [CrossRef]

21. Drumond, A.; Stojanovic, M.; Nieto, R.; Gimeno, L.; Liberato, M.L.R.; Ambrizzi, T.; Pauliquevis, T.; de Oliveira, M. Analysis of Dry and Wet Episodes in Eastern South America During 1980-2018 Using SPEI. In Proceedings of the 3rd International Electronic Conference on Atmospheric Sciences, ECAS-2020, Online Conference, 16-30 November 2020. [CrossRef]

22. Dee, D.P.; Uppala, S.M.; Simmons, A.J.; Berrisford, P.; Poli, P.; Kobayashi, S.; Andrae, U.; Balmaseda, M.A.; Balsamo, G.; Bauer, P.; et al. The ERA-Interim reanalysis: Configuration and performance of the data assimilation system. Q. J. R. Meteorol. Soc. 2001, 137, 553-597. [CrossRef]

23. Stohl, A.; Forster, C.; Frank, A.; Seibert, P.; Wotawa, G. Technical note: The Lagrangian particle dispersion model FLEXPART version 6.2. Atmos. Chem. Phys. 2005, 5, 2461-2474. [CrossRef]

24. Gimeno, L.; Nieto, R.; Drumond, A.; Castillo, R.; Trigo, R.M. Influence of the intensification of the major oceanic moisture sources on continental precipitation. Geophys. Res. Lett. 2013, 40, 1443-1450. [CrossRef]

25. Berrisford, P.; Dee, D.P.; Fielding, K.; Fuentes, M.; Kallberg, P.; Kobayashi, S.; Uppala, S.M. The ERA-Interim Archive; ERA Report Series, 2009, No. 1; ECMWF: Reading, UK; Available online: https:/ /www.ecmwf.int/node/8173 (accessed on 26 January 2021).

26. Harris, I.; Osborn, T.J.; Jones, P.; Lister, D. Version 4 of the CRU TS monthly high-resolution gridded multivariate climate dataset. Sci. Data 2020, 7, 109. [CrossRef]

27. University of East Anglia Climatic Research, Unit; Harris, I.C.; Jones, P.D. CRU TS4.03: Climatic Research Unit (CRU) Time-Series (TS) version 4.03 of high-resolution gridded data of month-by-month variation in climate (Jan. 1901-Dec. 2018). Centre Environ. Data Anal. 2020. [CrossRef]

28. Gimeno, L.; Drumond, A.; Nieto, R.; Trigo, R.M.; Stohl, A. On the origin of continental precipitation. Geophys. Res. Lett. 2010, 37, L13804. [CrossRef]

29. Reboita, M.S.; Ambrizzi, T.; Silva, B.A.; Pinheiro, R.F.; Porfírio da Rocha, R. The South Atlantic Subtropical Anticyclone: Present and Future Climate. Front. Earth Sci. 2019, 7, 1-15. [CrossRef]

30. Stohl, A.; James, P. A Lagrangian Analysis of the Atmospheric Branch of the Global Water Cycle. Part I: Method Description, Validation, and Demonstration for the August 2002 Flooding in Central Europe. J. Hydrometeorol. 2004, 5, 656-678. [CrossRef]

31. Stohl, A.; James, P. A Lagrangian analysis of the atmospheric branch of the global water cycle: Part II: Moisture Transports between Earth's Ocean Basins and River Catchments. J. Hydrometeorol. 2005, 6, 961-984. [CrossRef]

32. Gimeno, L.; Stohl, A.; Trigo, R.M.; Domínguez, F.; Yoshimura, K.; Yu, L.; Drumond, A.; Durán-Quesada, A.M.; Nieto, R. Oceanic and Terrestrial Sources of Continental Precipitation. Rev. Geophys. 2012, 50, RG4003. [CrossRef]

33. Drumond, A.; Marengo, J.M.; Ambrizzi, T.; Nieto, R.; Moreira, L.; Gimeno, L. The role of Amazon Basin moisture on the atmospheric branch of the hydrological cycle: A Lagrangian analysis. Hydrol. Earth Syst. Sci. 2014, 18, 2577-2598. [CrossRef]

34. Pampuch, L.A.; Drumond, A.; Gimeno, L.; Ambrizzi, T. Anomalous patterns of SST and moisture sources in the South Atlantic Ocean associated with dry events in southeastern Brazil. Int. J. Climatol. 2016, 36, 4913-4928. [CrossRef]

35. Sorí, R.; Marengo, J.M.; Nieto, R.; Drumond, A.; Gimeno, L. The Atmospheric Branch of the Hydrological Cycle over the Negro and Madeira River Basins in the Amazon Region. Water 2018, 10, 738. [CrossRef]

36. Gimeno, L.; Vázquez, M.; Eiras-Barca, J.; Sorí, R.; Stojanovic, M.; Algarra, I.; Nieto, R.; Ramos, A.M.; Durán-Quesada, A.M.; Dominguez, F. Recent progress on the sources of continental precipitation as revealed by moisture transport analysis. Earth Sci. Rev. 2020, 201, 103070. [CrossRef]

37. Numaguti, A. Origin and recycling processes of precipitating water over the Eurasian continent: Experiments using an atmospheric general circulation model. J. Geophys. Res. Atmos. 1999, 104, 1957-1972. [CrossRef]

38. Drumond, A.; Nieto, R.; Gimeno, L.; Trigo, R.M.; Ambrizzi, T.; De Souza, E. A Lagrangian Identification of the Main Sources of Moisture Affecting Northeastern Brazil during Its Pre-Rainy and Rainy Seasons. PLoS ONE 2010, 5, e11205. [CrossRef] [PubMed]

39. Drumond, A.; Nieto, R.; Gimeno, L.; Ambrizzi, T. A Lagrangian identification of major sources of moisture over Central Brazil and La Plata Basin. J. Geophys. Res. Atmos. 2008, 113, D14128. [CrossRef]

40. Nogués-Paegle, J.; Mechoso, C.R.; Fu, R.; Berbery, E.H.; Chao, W.C.; Chen, T.C.; Cook, K.; Diaz, A.F.; Enfield, D.; Ferreira, R.; et al. Progress in pan American CLIVAR research: Understanding the south American monsoon. Meteorologica 2002, 27, 1-30. Available online: https:/ / www.jsg.utexas.edu/fu/files/Nogues_Paegle_2002.pdf (accessed on 23 January 2021). 
41. Stojanovic, M.; Drumond, A.; Nieto, R.; Gimeno, L. Variations in moisture supply from the Mediterranean Sea during meteorological drought episodes over central Europe. Atmosphere 2018, 9, 278. [CrossRef]

42. Beguería, S.; Vicente-Serrano, S.M.; Reig, F.; Latorre, B. Standardized Precipitation Evapotranspiration Index (SPEI) revisited: Parameter fitting, evapotranspiration models, tools, datasets and drought monitoring. Int. J. Climatol. 2014, 34, 3001-3023. [CrossRef]

43. Vicente-Serrano, S.M.; Beguería, S. Short communication comment on "candidate distributions for climatological drought indices (SPI and SPEI)" by James H. Stagge et al. Int. J. Climatol. 2016, 36, 2120-2131. [CrossRef]

44. Marengo, J.A.; Ambrizzi, T.; Lincoln, M.A.; Barreto, N.J.C.; Reboita, M.S.; Ramos, A.M. Changing Trends in Rainfall Extremes in the Metropolitan Area of São Paulo: Causes and Impacts. Front. Clim. 2020, 2, 1-13. [CrossRef]

45. Rodwell, M.J.; Hoskins, B.J. Subtropical anticyclones and summer monsoons. J. Clim. 2001, 14, 3192-3211. [CrossRef] 